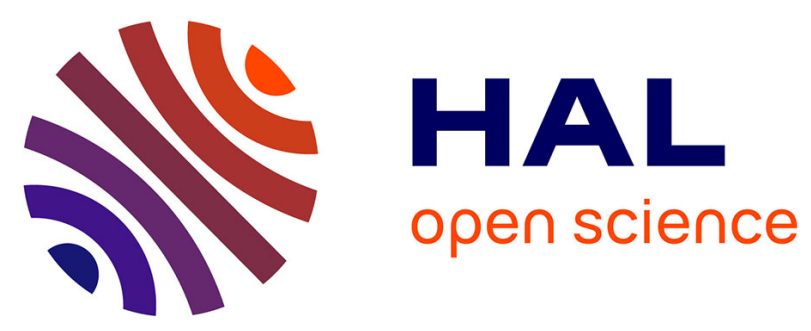

\title{
Temperature and pressure effects on the spin state of ferric ions in the $[\mathrm{Fe}($ sal-trien $)][\mathrm{Ni}(\mathrm{dmit})]$ spin crossover complex
}

P.A. Petra Á. Szilágyi, Stéphane Dorbes, Gábor Molnár, J.A. José Antonio

Real, Z. Zoltán Homonnay, C. Faulmann, Azzedine Bousseksou

\section{To cite this version:}

P.A. Petra Á. Szilágyi, Stéphane Dorbes, Gábor Molnár, J.A. José Antonio Real, Z. Zoltán Homonnay, et al.. Temperature and pressure effects on the spin state of ferric ions in the [Fe(sal-trien)][Ni(dmit)] spin crossover complex. Journal of Physics and Chemistry of Solids, 2010, 69 (11), pp.2681. 10.1016/j.jpcs.2008.06.106 . hal-00612401

\section{HAL Id: hal-00612401 \\ https://hal.science/hal-00612401}

Submitted on 29 Jul 2011

HAL is a multi-disciplinary open access archive for the deposit and dissemination of scientific research documents, whether they are published or not. The documents may come from teaching and research institutions in France or abroad, or from public or private research centers.
L'archive ouverte pluridisciplinaire HAL, est destinée au dépôt et à la diffusion de documents scientifiques de niveau recherche, publiés ou non, émanant des établissements d'enseignement et de recherche français ou étrangers, des laboratoires publics ou privés. 


\section{Author's Accepted Manuscript}

Temperature and pressure effects on the spin state of ferric ions in the $\left[\mathrm{Fe}\left(\mathrm{sal}_{2}\right.\right.$-trien $\left.)\right]\left[\mathrm{Ni}(\mathrm{dmit})_{2}\right]$ spin crossover complex

Petra Á. Szilágyi, Stéphane Dorbes, Gábor Molnár, José Antonio Real, Zoltán Homonnay, Christophe Faulmann, Azzedine Bousseksou

PII: $\quad$ S0022-3697(08)00336-3

DOI: $\quad$ doi:10.1016/j.jpcs.2008.06.106

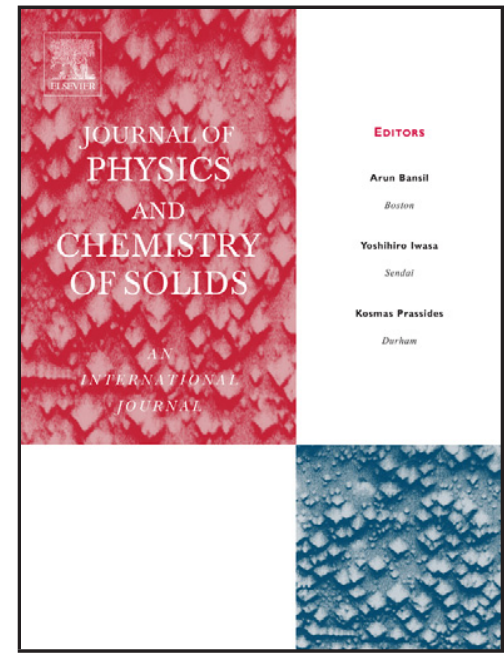

www.elsevier.com/locate/jpcs

Reference: $\quad$ PCS 5639

To appear in: Journal of Physics and Chemistry of Solids

Received date: $\quad 13$ September 2007

Revised date: $\quad 11$ April 2008

Accepted date: $\quad 18$ June 2008

Cite this article as: Petra Á. Szilágyi, Stéphane Dorbes, Gábor Molnár, José Antonio Real, Zoltán Homonnay, Christophe Faulmann and Azzedine Bousseksou, Temperature and pressure effects on the spin state of ferric ions in the $\left[\mathrm{Fe}\left(\mathrm{sal}_{2}-\right.\right.$ trien) $]\left[\mathrm{Ni}(\mathrm{dmit})_{2}\right]$ spin crossover complex, Journal of Physics and Chemistry of Solids (2008), doi:10.1016/j.jpcs.2008.06.106

This is a PDF file of an unedited manuscript that has been accepted for publication. As a service to our customers we are providing this early version of the manuscript. The manuscript will undergo copyediting, typesetting, and review of the resulting galley proof before it is published in its final citable form. Please note that during the production process errors may be discovered which could affect the content, and all legal disclaimers that apply to the journal pertain. 


\title{
Temperature and Pressure Effects on the Spin State of Ferric Ions in the $\left[\mathrm{Fe}\left(\mathrm{sal}_{2} \text {-trien)][Ni(dmit) }\right)_{2}\right.$ S Spin Crossover Complex
}

\author{
Petra Á. Szilágyi ${ }^{1,2}$, Stéphane Dorbes ${ }^{1}$, Gábor Molnár ${ }^{1}$, José Antonio Real ${ }^{3}$, Zoltán \\ Homonnay $^{2}$, Christophe Faulmann ${ }^{1}$, Azzedine Bousseksou ${ }^{1 *}$ \\ ${ }^{1}$ Laboratoire de Chimie de Coordination, CNRS UPR8241, Toulouse, France \\ ${ }^{2}$ Eötvös Loránd University, Laboratory of Nuclear Chemistry, Budapest, Hungary \\ ${ }^{3}$ Instituto de Ciencia Molecular, Universidad de Valencia, Valencia, Spain \\ * Corresponding author: boussek@lcc-toulouse.fr
}

\begin{abstract}
Thermal and pressure effects have been investigated on the $\left[\mathrm{Fe}\left(\mathrm{sal}_{2}\right.\right.$-trien $\left.)\right]\left[\mathrm{Ni}(\mathrm{dmit})_{2}\right]$ spin crossover complex by means of Mössbauer spectroscopic, calorimetric, X-ray diffraction and magnetic susceptibility measurements. The complex displays a complete thermal spin transition between the $S=5 / 2$ and $S=1 / 2$ spin states of $\mathrm{Fe}^{\mathrm{III}}$ near $245 \mathrm{~K}$ with a hysteresis loop of $c a .30 \mathrm{~K}$. This transition is characterised by a change of the enthalpy, $\Delta H_{\mathrm{HL}}=7 \mathrm{~kJ} / \mathrm{mol}$, entropy, $\Delta S_{\mathrm{HL}}=29 \mathrm{~J} / \mathrm{Kmol}$ and the unit cell volume, $\Delta V_{\mathrm{HL}}=15.4 \AA^{3}$. Under hydrostatic pressures up to $5.7 \mathrm{kbar}$ the thermal transition shifts to higher temperatures by $c a .16 \mathrm{~K} / \mathrm{kbar}$. Interestingly, at a low applied pressure of 500 bar the hysteresis loop becomes wider $(c a .61 \mathrm{~K})$ and the transition is blocked at $\sim 50 \%$ upon cooling indicating a possible (irreversible) structural phase transition under pressure.
\end{abstract}

Keywords: A. Inorganic compounds; B. High pressure; C. Magnetic properties; D. Phase transitions

\section{Introduction}

Spin-crossover (SC) complexes of transition metal ions $\left(3 d^{4}-3 d^{7}\right)$ have attracted much attention from the fundamental point of view [1-4]. These complexes represent one of the best examples of molecular bistability. They may be switched between their low spin (LS) and high spin (HS) electronic configurations, leading to important changes in their magnetic, dielectric and optical properties. This switching may be induced by varying the temperature, the pressure, the magnetic field and by light irradiation [5].

Although for both ferrous and ferric ions the change in the total spin in octahedral SC complexes is $\Delta S=2$, the actual change in metal-ligand bond-length (for a given donor-atom set) accompanying the spin-state change is less for the latter than for the former. This is the origin of the increased rate of inter-conversion of the ${ }^{2} T_{2}$ and ${ }^{6} A_{1}$ electronic configurations for iron(III), which has a consequence that the LIESST effect (light-induced excited spin-state trapping) is rarely observed for ferric compounds even at very low temperatures, in contrast to its ubiquitous occurrence for ferrous systems [6,7]. Some of the rare examples are reported in references [8,9]. For the same reason, Mössbauer spectra of ferric SC compounds display frequently relaxation lineshapes [2]. It is also often assumed in the literature that the smaller bond-length changes may explain that the occurrence of thermal hysteresis is rather rare for ferric complexes. Indeed, the great majority of them does not display first-order spin transition, but only a gradual spin conversion [7].

Electrical conductivity is a fundamental property of materials, which has been investigated in the domain of molecular science [10]. Compounds of type $\left(\mathrm{NR}_{4}\right)\left[\mathrm{M}(\mathrm{dmit})_{2}\right]_{\mathrm{x}}(\mathrm{x}>1)$, with nonintegral oxidation state, display interesting electron transport features. Combining SC and electrical conductivity was the aim of Dorbes et al. [11] when they first synthesised the 1:1 complex $\left[\mathrm{Fe}\left(\mathrm{sal}_{2}\right.\right.$-trien $\left.)\right]\left[\mathrm{Ni}(\mathrm{dmit})_{2}\right]$, precursor of the fractional oxidation state complex $\left[\mathrm{Fe}\left(\mathrm{sal}_{2}\right.\right.$-trien $\left.)\right]\left[\mathrm{Ni}(\mathrm{dmit})_{2}\right]_{3}[12]$. Analogously, similar properties have been studied on the salts of the $\left[\mathrm{Fe}(\mathrm{qsal})_{2}\right]^{+}$and $\mathrm{Fe}(\mathrm{R}-$ salEen $\left.)\right]^{+}$complex cations as well [13-19]. 
Since the $\left[\mathrm{Ni}(\mathrm{dmit})_{2}\right]^{\mathrm{n}-}$ anion is redox active [20] and the $\left[\mathrm{Fe}\left(\mathrm{sal}_{2} \text {-trien) }\right]^{+}\right.$cation is a wellknown SC compound [21] and displays a redox stability, combination of these ions appeared as a promising way to study the eventual coupling and synergy of these molecular features in one compound. The resultant 1:1 compound is built up of slabs of [Fe( sal $_{2}$-trien) $]^{+}$cations and layers of [Ni(dmit $\left.)_{2}\right]^{-}$anions [11], which alternate along the $c$-axis and spread out onto the $a b$ plane. In the HS state, the SC sites are constituted of severely distorted octahedral $\left[\mathrm{FeN}_{4} \mathrm{O}_{2}\right]$ centres, whereas in the LS state, the coordination octahedron is much more regular (Figure 1). This complex exhibits a first-order thermal phase transition with a large thermal hysteresis loop of the magnetic susceptibility, around $245 \mathrm{~K}\left(T_{1 / 2} \downarrow=228 \mathrm{~K}\right.$ and $\left.T_{1 / 2} \uparrow=258 \mathrm{~K}\right)$ (Figure 2).

It should be noted here that polymorphism has been observed since the first preparations of the triclinic $\left[\mathrm{Fe}\left(\mathrm{sal}_{2}\right.\right.$-trien $\left.)\right]\left[\mathrm{Ni}(\mathrm{dmit})_{2}\right]$ phase: a monoclinic phase, which remains $\mathrm{HS}$ whatever the temperature, is now systematically obtained. Up to now, attempts to synthesise again the triclinic phase, which appeared - by the way - stable for at least one year in ambient storage conditions, have failed despite the numerous syntheses. Such a disappearance of polymorphs is not a unique case, as reflected by the literature [22-25].

The aim of the present work was to complete the first observations of Dorbes et al. [11] by investigating in more details the effects of temperature and pressure on the spin state and associated properties of the triclinic $\left[\mathrm{Fe}\left(\mathrm{sal}_{2}\right.\right.$-trien $\left.)\right]\left[\mathrm{Ni}(\mathrm{dmit})_{2}\right]$ complex, which is one of the rare $\mathrm{Fe}^{\mathrm{III}}$ complexes displaying thermal spin transition with hysteresis. This first-order transition occurs without a change of the space group of the crystal $(P \overline{\mathbf{1}})$, creating thus an interesting scope for the comparison of experimental observations, especially pressure effects, with theoretical predictions [26].

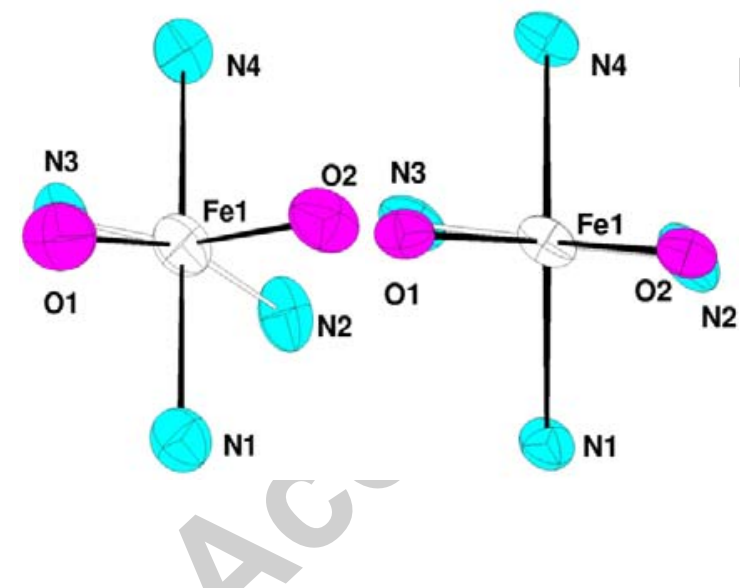

Figure 1. Structure of the coordination octahedron of $\mathrm{Fe}^{\mathrm{III}}$ ions in the $\left[\mathrm{Fe}\left(\mathrm{sal}_{2}\right.\right.$-trien $\left.)\right]\left[\mathrm{Ni}(\mathrm{dmit})_{2}\right]$ complex, in the HS $((S=5 / 2)$ left $)$ and LS $((S=1 / 2)$ right) states [11].

\section{Experimental}

Mössbauer measurements were carried out in a flow-type liquid nitrogen cryostat using a conventional constant acceleration type Mössbauer spectrometer. $\gamma$-rays were provided by a ${ }^{57} \mathrm{Co}(\mathrm{Rh})$ source $(15 \mathrm{mCi})$. The spectrum evaluations were done with the assumption of Lorentzian line shapes using the MossWinn3.0 software [27]. All isomer shifts are given relative to $\alpha$-Fe at room temperature.

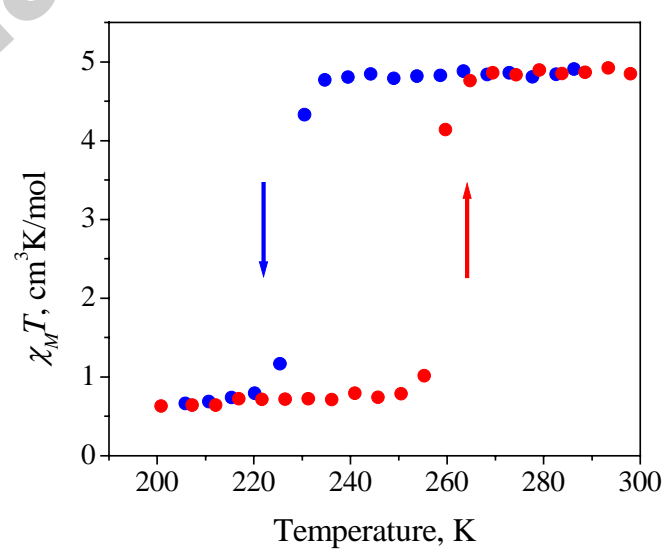

Figure 2. Magnetic susceptibility data for the $\quad\left[\mathrm{Fe}\left(\mathrm{sal}_{2}\right.\right.$-trien $\left.)\right]\left[\mathrm{Ni}(\mathrm{dmit})_{2}\right] \quad$ complex displaying a thermal hysteresis loop [11]. 
Differential Scanning Calorimetry (DSC) analysis was carried out in a NETZSCH DSC 204 instrument, under He purging gas $\left(20 \mathrm{~cm}^{3} / \mathrm{min}\right)$ at a $10 \mathrm{~K} / \mathrm{min}$ scanning rate, in both, heating and cooling modes. Temperature and enthalpy $(\Delta H)$ were calibrated by using melting transition of standard materials (Hg, In, Sn).

Crystallographic unit cell parameters have been collected between 150 and $290 \mathrm{~K}$ in the heating and cooling modes by steps of $20 \mathrm{~K}$ using an Xcalibur (Oxford Instruments) X-ray diffractometer equipped with an Oxford Cryosystems cooler device (Cryojet). Unit cell parameters for every temperature were determined by using the CrysAlis CCD softwares [28]. Magnetic susceptibility measurements at high pressures were carried out in a magnetic field of 2 T using a clamp-type, hardened beryllium bronze (CuBe) cell. Hydrostatic conditions are obtained by mixing the powder samples with a pressure transmitting mineral oil. Details of the pressure cell have been given in ref. [29].

\section{Results and Discussion}

Mössbauer spectra at selected temperatures are displayed in Figure 3. Spectrum parameters and errors for all spectra recorded are listed in Table 1.

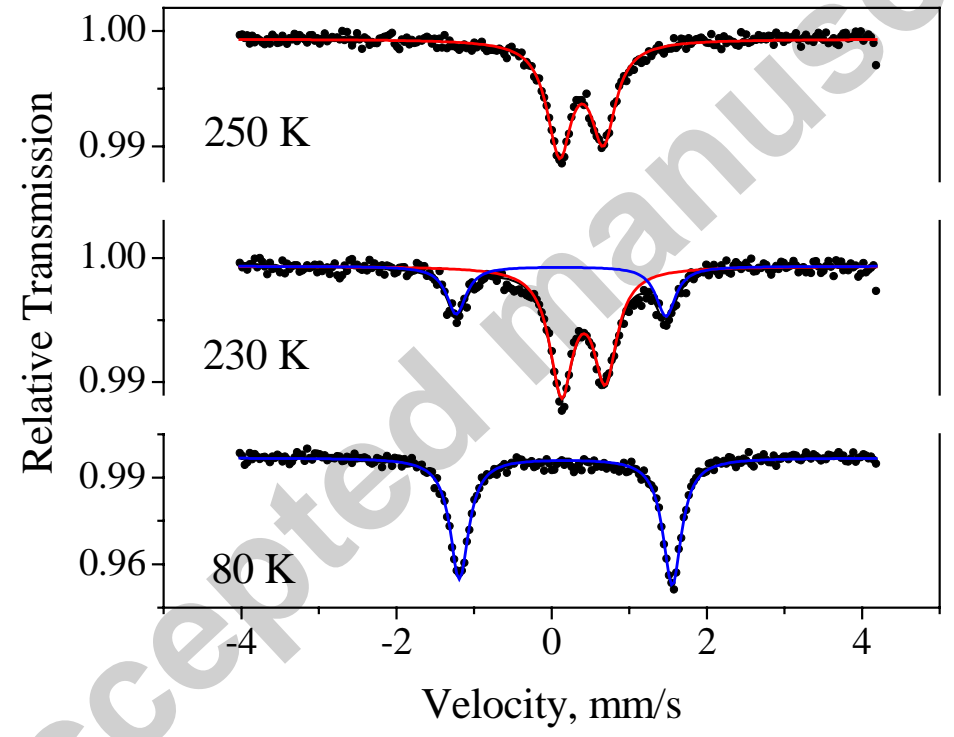

Figure 3. Mössbauer spectra of the $\left[\mathrm{Fe}\left(\mathrm{sal}_{2}\right.\right.$-trien $\left.)\right]\left[\mathrm{Ni}(\mathrm{dmit})_{2}\right]$ complex at selected temperatures.

The hyperfine parameters of both doublets correspond well to the typical parameters of ferric HS $\left(S=5 / 2, \delta_{250 \mathrm{~K}}=0.382(3) \mathrm{mm} / \mathrm{s}, \Delta_{250 \mathrm{~K}}=0.565(4) \mathrm{mm} / \mathrm{s}\right)$ and LS $\left(S=1 / 2, \delta_{80 \mathrm{~K}}=0.182(1) \mathrm{mm} / \mathrm{s}\right.$, $\left.\Delta_{80 \mathrm{~K}}=2.742(3) \mathrm{mm} / \mathrm{s}\right)$ complexes. Especially the high quadrupole splitting for the LS form is very characteristic [30]. The fact that only one component appears in the spectra recorded at $80 \mathrm{~K}$ and $250 \mathrm{~K}$ proves the occurrence of a complete spin transition in the system in both ways. This finding is in agreement with the magnetic susceptibility data $\left(\chi_{\mathrm{M}} T_{250 \mathrm{~K}}=4.84\right.$ $\mathrm{cm}^{3} \mathrm{Kmol}^{-1}$ and $\chi_{\mathrm{M}} T_{80 \mathrm{~K}}=0.66 \mathrm{~cm}^{3} \mathrm{Kmol}^{-1}$ ), but only the Mössbauer spectra can prove the completeness of the transition unambiguously, especially in the presence of other paramagnetic species. The inter-conversion of the spin states in many instances is so rapid for ferric complexes that the separate contributions to the ${ }^{57} \mathrm{Fe}$ Mössbauer spectra are not resolved. This is not the case for the $\left[\mathrm{Fe}\left(\mathrm{sal}_{2}\right.\right.$-trien $\left.)\right]\left[\mathrm{Ni}(\mathrm{dmit})_{2}\right]$ complex, where no line broadening due to relaxation effects is displayed in the spectra. (The small, temperature- 
independent asymmetry of the HS and the LS doublets is a typical signature of a texture effect in the system.) One should note also that the coexistence of both doublets (HS and LS) is clearly observed in the spectrum at $230 \mathrm{~K}$, i.e. in the descending branch of the thermal hysteresis loop.

Table 1. Hyperfine parameters (and their statistical errors) for the $\left[\mathrm{Fe}\left(\mathrm{sal}_{2}\right.\right.$-trien)][Ni(dmit) $\left.{ }_{2}\right]$ complex at various temperatures and spin states. $\mathrm{N} / \mathrm{N}_{\text {tot }}, \delta$ and $\Delta$ signify the relative amount of the subspectra, the isomer shift and the quadrupole splitting, respectively.

\begin{tabular}{|c|c|c|c|c|c|c|c|}
\hline \multirow{2}{*}{\multicolumn{2}{|c|}{$T(\mathrm{~K})$}} & \multicolumn{3}{|c|}{ HS } & \multicolumn{3}{|c|}{ LS } \\
\hline & & $\mathrm{N} / \mathrm{N}_{\text {tot }}(\%)$ & $\delta(\mathrm{mm} / \mathrm{s})$ & $\Delta(\mathrm{mm} / \mathrm{s})$ & $\mathrm{N} / \mathrm{N}_{\text {tot }}(\%)$ & $\delta(\mathrm{mm} / \mathrm{s})$ & $\Delta(\mathrm{mm} / \mathrm{s})$ \\
\hline \multirow{7}{*}{ ن } & 250 & 100 & $0.382(3)$ & $0.565(4)$ & - & - & - \\
\hline & 230 & 73.5 & $0.407(2)$ & $0.564(4)$ & 26.5 & $0.121(5)$ & $2.70(1)$ \\
\hline & 200 & - & - & - & 100 & $0.148(2)$ & $2.721(4)$ \\
\hline & 160 & - & - & - & 100 & $0.157(1)$ & $2.732(2)$ \\
\hline & 140 & - & - & - & 100 & $0.165(2)$ & $2.723(4)$ \\
\hline & 120 & - & - & - & 100 & $0.175(1)$ & $2.73(2)$ \\
\hline & 80 & - & - & - & 100 & $0.182(1)$ & $2.742(3)$ \\
\hline \multirow{6}{*}{ 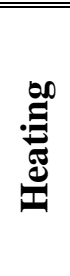 } & 250 & 18.7 & $0.37(4)$ & $0.64(5)$ & 81.3 & $0.128(2)$ & $2.705(4)$ \\
\hline & 260 & 24.0 & $0.38 *$ & $0.59 *$ & 76.0 & $0.124(2)$ & $2.716(5)$ \\
\hline & 275 & 83.7 & $0.383(2)$ & $0.553(4)$ & 16.3 & $0.11^{*}$ & $2.65(4)$ \\
\hline & 290 & 100 & $0.365(3)$ & $0.548(6)$ & - & - & - \\
\hline & 300 & 100 & $0.351(4)$ & $0.544(6)$ & - & - & - \\
\hline & 310 & 100 & $0.354(5)$ & $0.540(7)$ & & - & - \\
\hline
\end{tabular}

*These parameters were fixed during the fit.

The HS ferric cation has a $t_{2 \mathrm{~g}}{ }^{3} e_{\mathrm{g}}{ }^{2}\left({ }^{6} S\right)$ electronic ground state and a spherical symmetry. Any electric field gradient (EFG) could arise solely from charges external to the central atom. It is unlikely that there would be any low-lying excited levels, thus no significant change in the quadrupole splitting is expected. The situation, however, is somewhat more complex for LS $\mathrm{Fe}^{3+}$ systems and usually considerable temperature dependence may be observed. The $t_{2 \mathrm{~g}}{ }^{5}\left({ }^{2} \mathrm{~T}\right)$ state corresponds to a single electron hole in an otherwise cubic triplet level. In complexes with lower symmetry than cubic, further degeneracy is removed, thereby producing a nonzero EFG and quadrupole splitting consequently. Thermal population of the low-lying excited states then causes a variation in the electron configuration with temperature, and since the distinct $3 d$ orbitals have different contributions to the electric field gradients, there is usually a strong temperature dependence of the quadrupole splitting [30]. Therefore it is noteworthy that the quadrupole splitting values for the LS state display practically no temperature dependence between $230 \mathrm{~K}$ and $80 \mathrm{~K}$. This phenomenon may be due to the electronic ground state being well isolated.

As the SC phenomena involve a transfer of electrons between the antibonding $e_{\mathrm{g}}$ and nonbonding $t_{2 \mathrm{~g}}$ orbitals, the metal-to-ligand bond distances increase remarkably when going from the LS to the HS state. This results in a drastic change in the density of vibrational states, mainly in the metal-ligand skeletal vibrational modes. This leads, of course, to significantly higher vibrational entropy in the HS state [31]. The entropy change accompanying the SC can be represented as the sum of electronic, configurational and motional, i.e. vibrational, rotational and translational terms. The two latter can be neglected in solid state, so can be the configurational term in the absence of disorder of orientation. The electronic term contains spin and orbital contributions. As the orbital contribution may be neglected in low-symmetry complexes, the electronic term is given by the spin-only value, 
$\Delta S_{\mathrm{el}}=R \cdot \ln \left(\mathrm{S}_{\mathrm{HS}} / \mathrm{S}_{\mathrm{LS}}\right)=R \cdot \ln 3=9.134 \mathrm{~J} / \mathrm{Kmol}$. In the case of ferrous SC compounds, many data are available for the variation of the entropy, which is typically about $\Delta S \sim 30-60 \mathrm{~J} / \mathrm{Kmol}$, including the electronic contribution, $\Delta S_{\mathrm{el}}=R \cdot \ln 5=13.4 \mathrm{~J} / \mathrm{Kmol}$. However, for ferric complexes only a few data are available. Nevertheless, one can expect the change of entropy accompanying the spin transition to be typically smaller than in the case of ferrous compounds, since the electronic contribution is smaller and, more significantly, the vibrational contribution should be smaller as well, since the bond lengths do not undergo such a drastic change as in the case of $\mathrm{Fe}^{2+}$. This was shown by Sorai et al. [32] when studying the $\left[\mathrm{Fe}(\text { acpa })_{2}\right] \mathrm{PF}_{6}(\Delta S=36.2 \mathrm{~J} / \mathrm{Kmol})$ complex and by Conti et al. [33] for various [Fe(3EtOsalAPA $]^{2+}$ complexes $(\Delta S \sim 30-40 \mathrm{~J} / \mathrm{Kmol})$. In order to determine the change of the vibrational entropy in the $\left[\mathrm{Fe}\left(\mathrm{sal}_{2}\right.\right.$-trien $\left.)\right]\left[\mathrm{Ni}(\mathrm{dmit})_{2}\right]$ complex, DSC measurements have been carried out (Figure 4). The DSC curves exhibit singularities around the spin transition temperatures. Interestingly, two maxima are observed in the heating mode and a shoulder adjacent to the singularity representing the spin transition can also be seen in the cooling mode. From the area of the peaks, the total change of enthalpy and entropy induced by the spin transition can be determined as $\Delta H_{\mathrm{HL}}=7 \mathrm{~kJ} / \mathrm{mol}$ and $\Delta S_{\mathrm{HL}}=\Delta H / T_{\mathrm{c}}=29 \mathrm{~J} / \mathrm{Kmol}$ (and $T_{\mathrm{c}} \approx\left(T_{1 / 2} \downarrow+T_{1 / 2} \uparrow\right) / 2=243 \mathrm{~K}$ ). Therein, the vibrational entropy variation is: $\Delta S_{\mathrm{vib}}=20 \mathrm{~J} / \mathrm{Kmol}\left(\Delta S_{\mathrm{tot}}=R \cdot \ln 3+\Delta S_{\mathrm{vib}}\right)$, which is a rather low value, even comparing to other ferric SC systems [1].

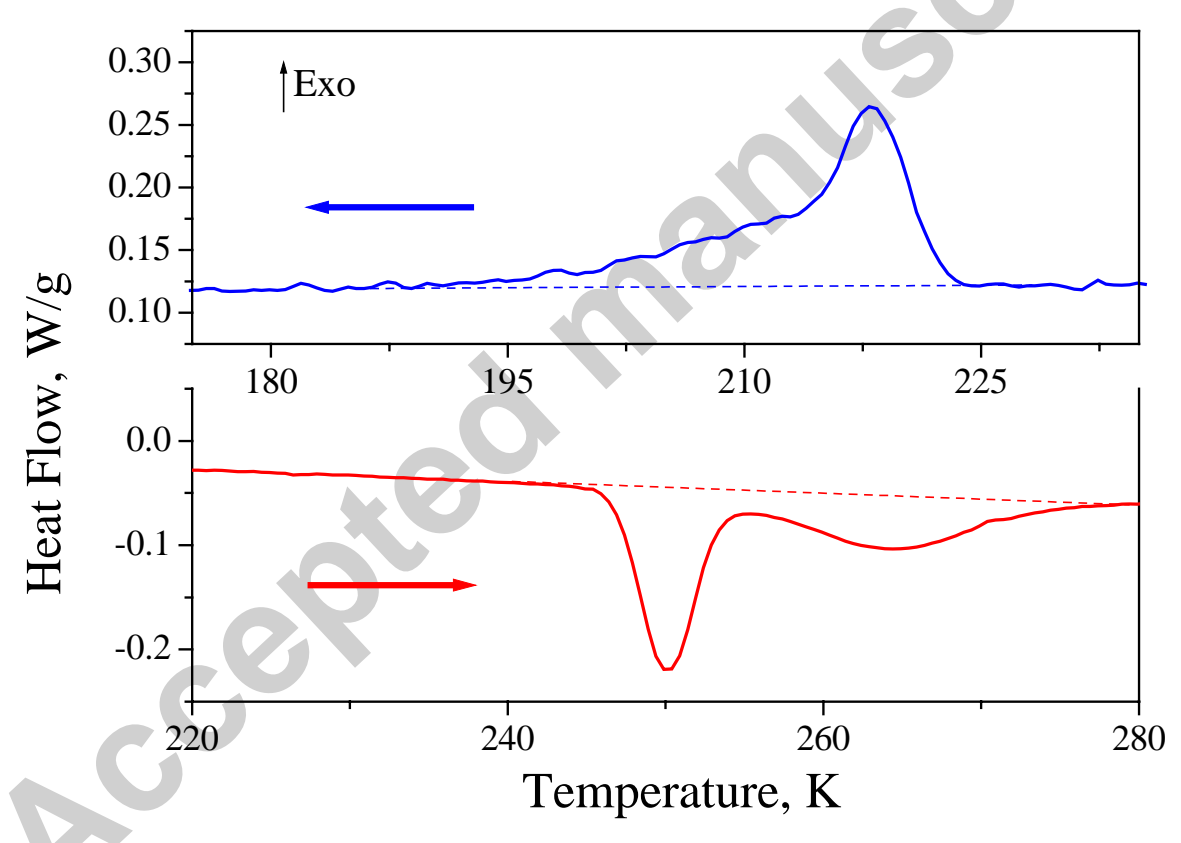

Figure 4. DSC curves of the $\left[\mathrm{Fe}\left(\mathrm{sal}_{2}\right.\right.$-trien $\left.)\right]\left[\mathrm{Ni}(\mathrm{dmit})_{2}\right]$ complex in the heating and cooling cycles.

It is well known that the spin crossover is accompanied by an important change in the volume of the unit cell. Furthermore, first-order spin transitions are often accompanied by a change of the space group as well [34]. Remarkably, in the case of [Fe( $\mathrm{sal}_{2}$-trien)][Ni(dmit) $\left.)_{2}\right]$ both the HS and LS forms display the same triclinic $P \overline{\mathbf{1}}$ space group. The main structural modification due to the spin crossover concerns the Fe-N bonds. When the electrons go from the $e_{\mathrm{g}}$ to the $t_{2 \mathrm{~g}}$ orbital, i.e. during the spin transition from HS to LS state, a strengthening of the metaldonor atom bonds occurs (decrease in the Fe-N bond distance), but the N-Fe-N angles are also strongly affected. The change of the unit cell volume is very important (typically $1-6 \%$ in $\mathrm{Fe}^{\mathrm{II}} \mathrm{N}_{6}$ complexes) hence relatively small external pressure (i.e. a few hundred bars) can affect the spin state of the system by stabilising the LS form. The determination of $\Delta V_{\mathrm{HL}}$ from the 
two structures recorded at $295 \mathrm{~K}$ (HS) and $180 \mathrm{~K}$ (LS) is not accurate enough since the thermal expansion of the lattice must also be taken into account. Therefore we have determined the unit cell parameters in a wide temperature range. The upper graph in Figure 5 shows the variation of the volume of the unit cell of the $\left[\mathrm{Fe}\left(\mathrm{sal}_{2}\right.\right.$-trien)][Ni(dmit) $\left.{ }_{2}\right]$ complex as a function of the temperature. From this figure, the coefficients of volumetric thermal expansion - defined as $\alpha_{\mathrm{V}}=1 / V_{235 \mathrm{~K}}(\mathrm{~d} V / \mathrm{d} T)$ - in the two spin states are $\alpha_{\mathrm{HS}}=192( \pm 1) 10^{-6} \mathrm{~K}^{-1}$, $\alpha_{\mathrm{LS}}=163( \pm 2) 10^{-6} \mathrm{~K}^{-1}$ and the variation of the unit cell volume upon the spin transition is $\Delta V_{\mathrm{HL}}=15.4 \AA^{3}$. It is worth noting that the $\Delta V / V_{295 \mathrm{~K}}$ ratio is only about $0.9 \%$, which is a rather small value.

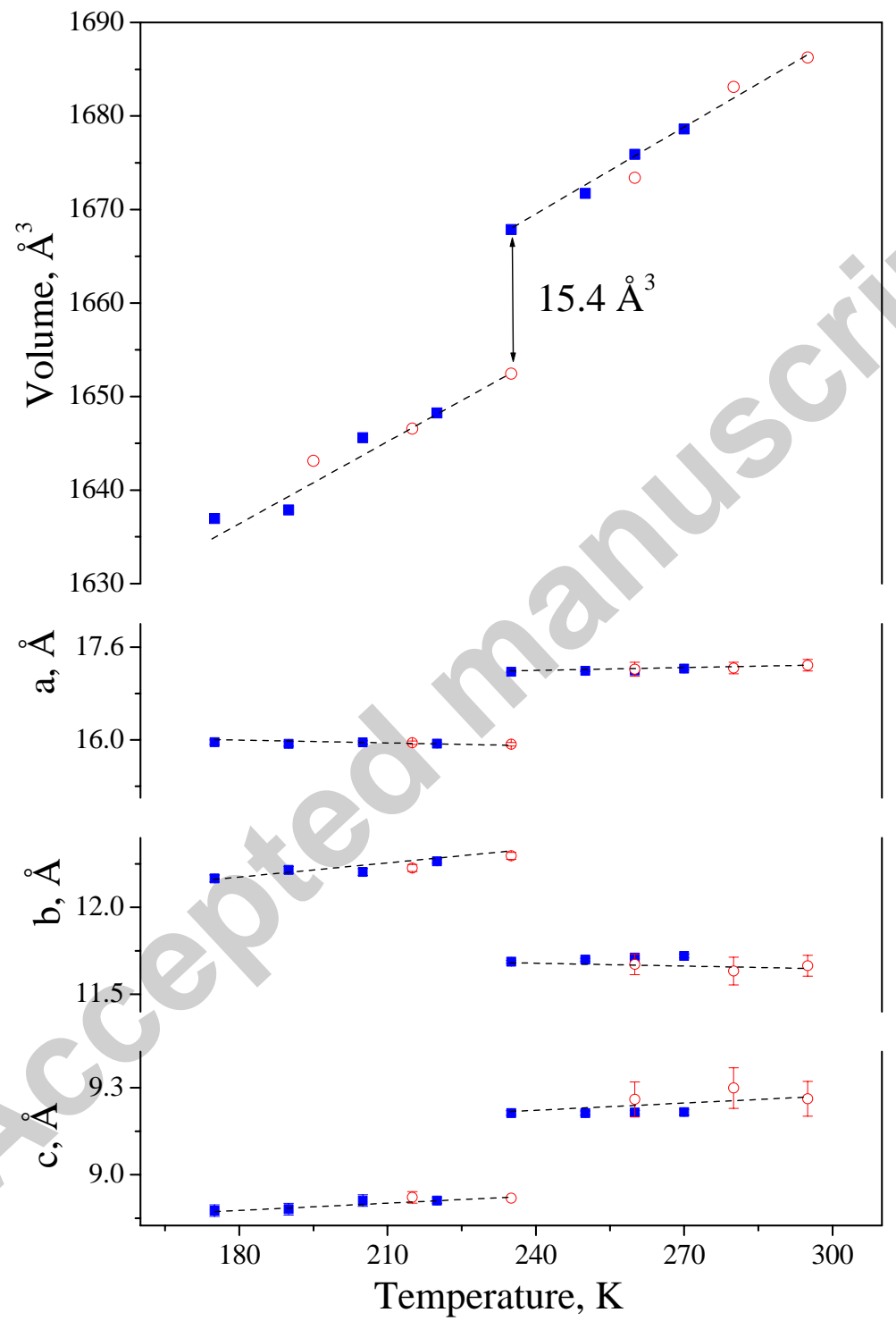

Figure 5. Variation of unit cell volume and the cell parameters in the $\left[\mathrm{Fe}\left(\mathrm{sal}_{2} \text {-trien)][Ni(dmit }\right)_{2}\right]$ complex as a function of temperature. Squares (dots) display the data obtained when the temperature was decreased (increased). Lines are inserted to guide the eye.

Beside the volume change, the anisotropy of the unit cell contraction is also a general feature for SC materials, since they often crystallise in low symmetry space groups [35]. As a first approximation, this anisotropy may be analysed as a function of the temperature dependence of the unit cell parameters within a wide temperature range that includes the spin crossover (Figure 5). It is remarkable that in the $\left[\mathrm{Fe}\left(\mathrm{sal}_{2}\right.\right.$-trien $\left.)\right]\left[\mathrm{Ni}(\mathrm{dmit})_{2}\right]$ complex one can observe the 
dilatation only in the $a c$ plane while the value of $b$ decreases in the course of the LS $\rightarrow$ HS spin transition. It is also clear that this decrease of $b$ is related only to the spin state change and is not a "negative thermal expansion" phenomenon. Such anisotropic change of volume may complicate pressure effects and may lead to additional structural changes under pressure when compared to the thermal transition.

The transition temperature $\left(T_{\mathrm{c}}\right)$ and the pressure are related to the variation of the volume of the unit cell. From the change of volume in the course of the spin transition, the effect of applied pressure on the thermal SC can be estimated, using the Clausius-Clapeyron equation from which the stabilisation of the LS state under pressure can be estimated as $\mathrm{d} T_{\mathrm{C}} / \mathrm{d} p=\Delta V_{\mathrm{HL}} / \Delta S_{\mathrm{HL}}=16 \mathrm{~K} / \mathrm{kbar}$ (since both $\Delta S_{\mathrm{HL}}$ and $\Delta V_{\mathrm{HL}}$ are positive values). Magnetic susceptibility measurements have been carried out in order to determine the effects of hydrostatic pressure on the $\left[\mathrm{Fe}\left(\mathrm{sal}_{2}\right.\right.$-trien $\left.)\right]\left[\mathrm{Ni}(\mathrm{dmit})_{2}\right] \mathrm{SC}$ complex. Curves recorded at various applied pressure values are displayed in Figure 6.

As expected, the hysteresis loop shifts toward higher temperatures with increasing applied pressure. The pressure shift of $T_{\mathrm{c}}$ is approximately $16( \pm 1) \mathrm{K} / \mathrm{kbar}$, which is in excellent agreement with the value estimated above, but no comparison can be safely made because of a remarkable additional phenomenon. As shown in Figure 6, when cooling the system under 0.5 kbar applied pressure the transition stops at approximately halfway and the system remains blocked in this intermediate state instead of a complete transition into the LS state. Then, in the heating mode, the system first relaxes to the LS state before returning to the HS state. This phenomenon is most probably due to an additional structural change induced by the pressure. When raising the applied pressure (i.e. at higher temperatures), the intermediate state becomes less and less apparent. Nevertheless, when releasing the applied pressure in the cell, the pressure effects turn out to be irreversible to some extent.

It is interesting to note also that at $0.5 \mathrm{kbar}$ the hysteresis width is wider $\left(\Delta T_{\mathrm{p}=500 \mathrm{bar}}=61 \mathrm{~K}\right)$ when compared to the case of atmospheric pressure $\left(\Delta T_{\mathrm{p}=1 \mathrm{~atm}}=30 \mathrm{~K}\right)$, which is exactly the opposite of what is usually observed experimentally and expected from theoretical considerations. In fact, according to the Ising-like model developed in ref. [34] the hysteresis loop width is proportional to $J / T_{\mathrm{c}}$, where $J$ is a phenomenological, mean-field parameter for the cooperativity and $T_{\mathrm{c}}$ is the transition temperature. Since such low pressures are not expected to affect considerably the value of $J$, the hysteresis width will decrease with increasing $T_{\mathrm{C}}$ values under pressure.

A few anomalous examples have already been reported in literature when the hysteresis width was found to increase under pressure [24, 37-42]. The most obvious explanation of this phenomenon can be a pressure induced additional structural change, since the sharp discontinuity in the phase diagram below $0.5 \mathrm{kbar}$, followed by a "regular" ClausiusClapeyron behaviour above 0.5 kbar is very difficult to explain in any other ways. However, a few different explanations for this unusual phenomenon can also be mentioned, such as cracks of particles which is not expected in our case where the hydrostatic conditions were maintained during the experiments and which should result, in any case, in a more gradual transition and narrowing of the hysteresis [43]. The variation of thermodynamic parameters could also affect the hysteresis width. However, at 0.5 kbar pressure this effect cannot be regarded as significant [24, 44-48]. Let us also note that further raising the applied pressure from 0.5 to $5.7 \mathrm{kbar}$ leads to a monotonous decrease of the hysteresis width (from 61 to $44 \mathrm{~K}$ ), suggesting that no further structural changes occur above $c a$. 0.5 kbar. This is better seen in the $(p, T)$ phase diagram (Figure 7$)$, which reveals clearly a "classical” behaviour between 0.5 
and 5.7 kbar with a higher Clausius-Clapeyron slope for the HS $\rightarrow$ LS transition $\left(\mathrm{d} T_{1 / 2} \downarrow / \mathrm{d} p=17( \pm 0.5) \quad \mathrm{K} / \mathrm{kbar}\right) \quad$ when compared to the reverse $\mathrm{LS} \rightarrow \mathrm{HS}$ transition $\left(\mathrm{d} T_{1 / 2} \uparrow / \mathrm{d} p=14( \pm 1) \mathrm{K} / \mathrm{kbar}\right)$. From this, one can estimate that the first-order spin transition is suppressed by the applied pressure above $c a .22 \mathrm{kbar}(660 \mathrm{~K})$, which is, of course, beyond the thermal decomposition temperature of the complex. The phase diagram confirms also the obvious discontinuous behaviour between 1.013 bar and $0.5 \mathrm{kbar}$, typical of structural phase transition.

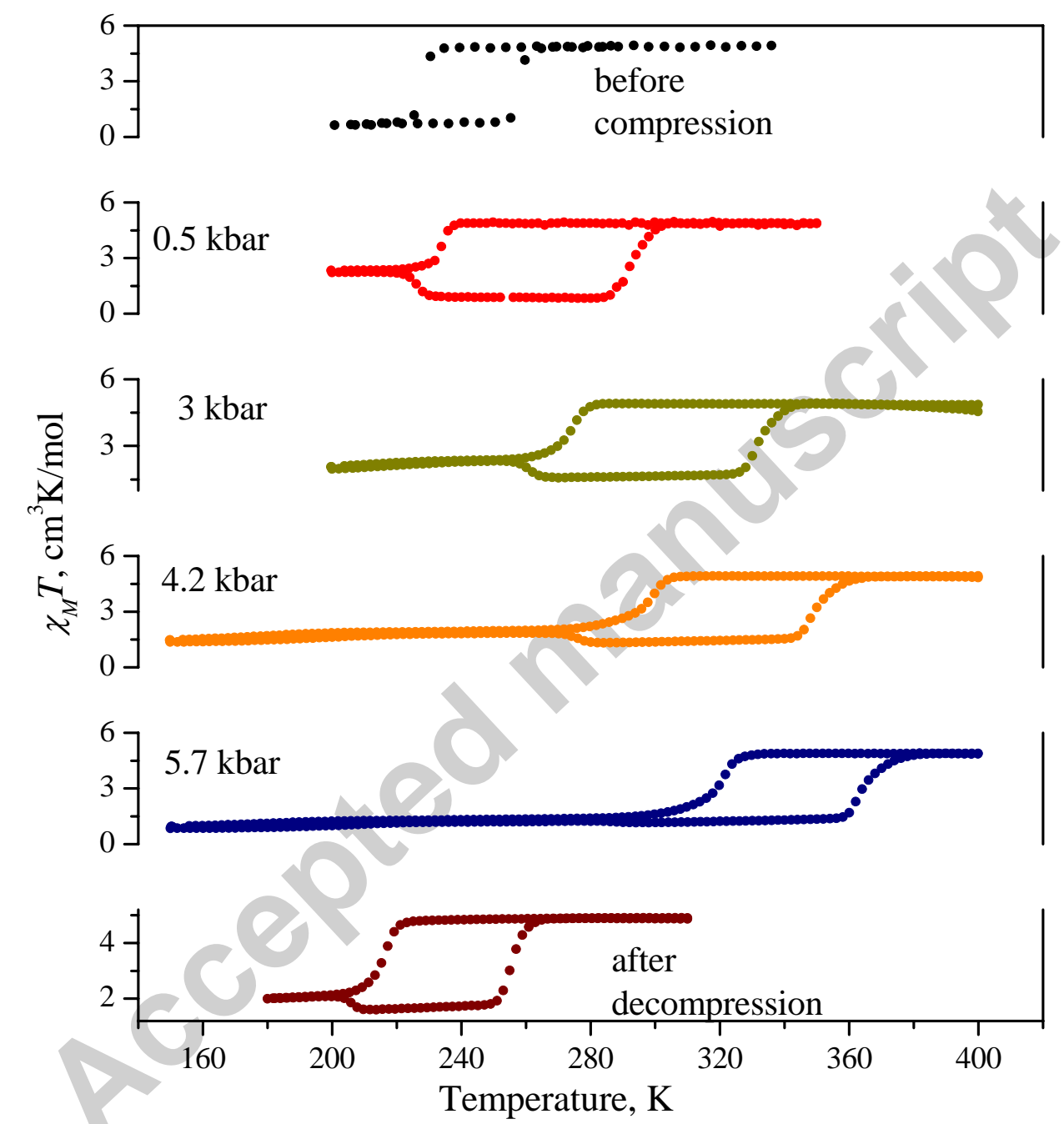

Figure 6. Magnetic susceptibility curves as a function of temperature for the $\left[\mathrm{Fe}\left(\mathrm{sal}_{2}\right.\right.$-trien $\left.)\right]\left[\mathrm{Ni}(\mathrm{dmit})_{2}\right]$ complex at various applied pressure values. 


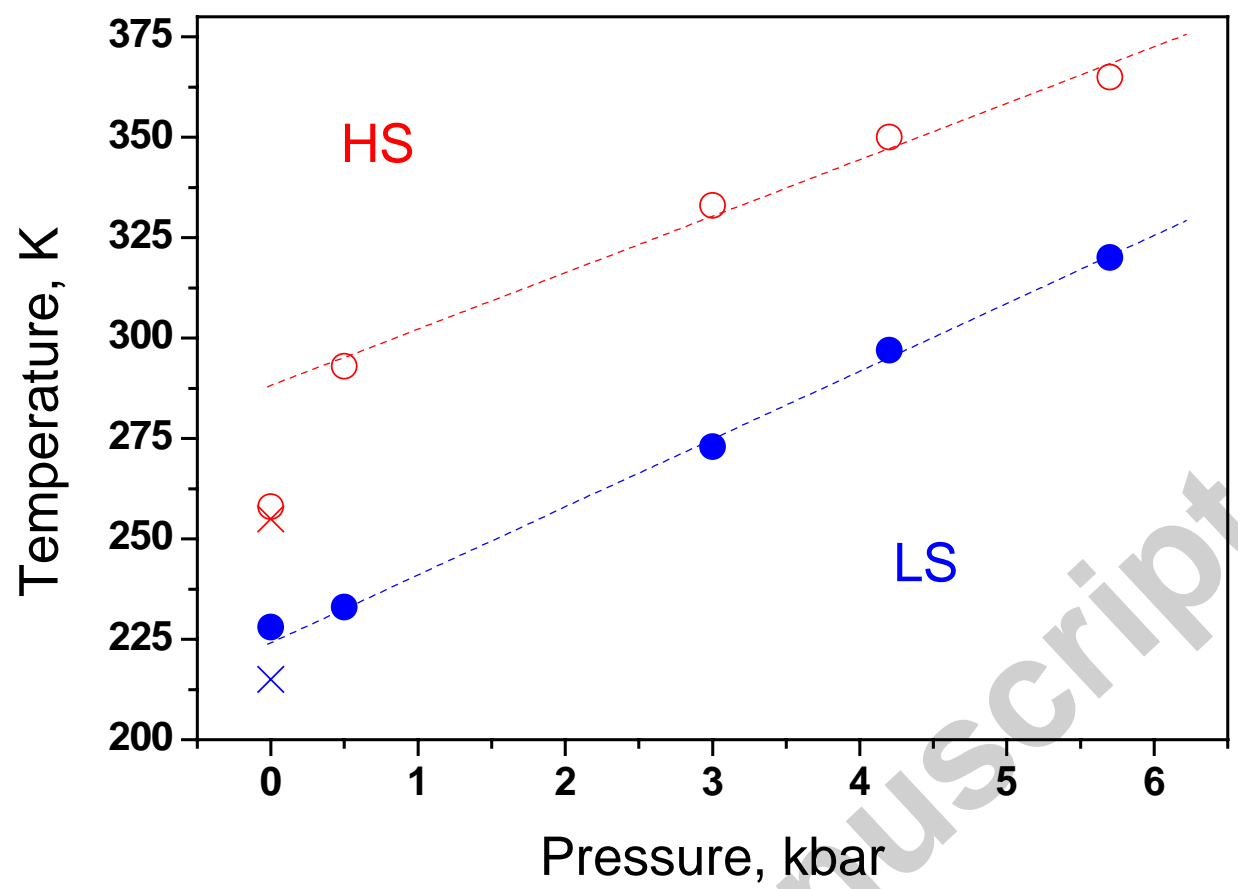

Figure 7. $(p, T)$ phase diagram of the $\left[\mathrm{Fe}\left(\mathrm{sal}_{2}\right.\right.$-trien) $]\left[\mathrm{Ni}(\mathrm{dmit})_{2}\right]$ complex. Open (closed) symbols display the transition temperatures obtained in the heating (cooling) modes at different applied pressures. The two crosses show the transition temperatures after releasing the applied pressure. Lines represent linear fit on the data between 0.5 and $5.7 \mathrm{kbar}$ (extrapolated to $0 \mathrm{kbar}$ ).

\section{Conclusions}

Thermal and pressure effects on the $\left[\mathrm{Fe}\left(\mathrm{sal}_{2}\right.\right.$-trien $\left.)\right]\left[\mathrm{Ni}(\mathrm{dmit})_{2}\right]$ spin crossover complex have been investigated. A complete thermal spin transition $(S=1 / 2 \leftrightarrow S=5 / 2)$ of the compound has been evidenced by Mössbauer spectroscopy in agreement with the previous magnetic susceptibility measurements. From DSC measurements, the variation of the enthalpy and entropy following the thermal spin transition has been determined as $\Delta H_{\mathrm{HL}}=7 \mathrm{~kJ} / \mathrm{mol}$ and $\Delta S_{\mathrm{HL}}=29 \mathrm{~J} / \mathrm{Kmol}$. This latter value points to a relatively small change of the vibrational entropy upon the spin transition. X-ray diffraction data were collected at different temperature values and the discontinuous variation of the unit cell volume accompanying the first order spin transition was determined $\left(\Delta V_{\mathrm{HL}}=15.4 \AA^{3}\right)$, which corresponds to $0.9 \%$ volume change. Furthermore, it was found that the higher unit cell volume value in the HS state is solely due to the dilatation of the $a c$ plane, whilst the unit cell gets contracted along the $b$ direction. Magnetic susceptibility measurements under hydrostatic pressure revealed the expected positive shift of transition temperature $(\sim 16 \mathrm{~K} / \mathrm{kbar})$ in agreement with the calculated Clausius-Clapeyron slope $\left(\Delta V_{\mathrm{HL}} / \Delta S_{\mathrm{HL}}\right)$. However, this agreement must only be a coincidence as a probable structural change has been observed at low applied pressure and these pressure induced changes turned out to be partly irreversible. Further work using structural and spectroscopic methods under pressure will be necessary to elucidate the mechanism of pressure effects on the system. Let us finally note here that the investigation of light induced 
effects, inside and outside the hysteresis loop, can be an interesting further perspective of this work, even if the dark colour of the sample makes these experiments challenging.

\section{Acknowledgments}

This work was supported by the European program COST D35. P. Á. Sz. is grateful to the Embassy of France in Hungary, for her PhD grant. Lionel Rechignat and Jean-François Meunier (LCC) are acknowledged for their technical help and Marc Nardone (LNCMP, Toulouse) for the conception of the high pressure cell.

\section{References}

[1] P. Gütlich, H. A. Goodwin, Editors, Spin Crossover in Transition Metal Compounds IIII, Topics in Current Chemistry vol. 233-235, Springer, Berlin (2004).

[2] P. Gütlich, A. Hauser, H. Spiering, Angew. Chem. Int. Ed. Engl. 33 (1994) 2024.

[3] A. Bousseksou, G. Molnár, G. Matouzenko, Eur. J. Inorg. Chem. (2004) 4353

[4] J. A. Real, A. B. Gaspar, M. Carmen Munoz, Dalton Trans. (2005) 2062.

[5] F. Varret, A. Bleuzen, K. Boukheddaden, A. Bousseksou, E. Codjovi, C. Enachescu, A. Goujon, J. Linares, N. Menendez, M. Verdaguer, Pure Appl. Chem. 74 (2002) 2093.

[6] A. Hauser, Top. Curr. Chem. 234 (2004) 155.

[7] P. Van Königsbruggen, Y. Maeda, H. Oshio, Top. Curr. Chem. 233( 2004) 259.

[8] S. Hayami, Z. Z. Gu, M. Shiro, Y. Einaga, A. Fujishima, O. Sato, J. Am. Chem. Soc. 122 (2000) 7126.

[9] G. Juhász, S. Hayami, O. Sato, Y. Maeda, Chem. Phys. Lett. 364 (2002) 164.

[10] P. Cassoux, J. Miller, in Chemistry of Advanced Materials: An Overview, ed. L. V. Interrante, M. J. Hampden-Smith, New York, USA (1998), p. 19.

[11] S. Dorbes, L. Valade, J. A. Real, C. Faulmann, Chem. Commun. (2005) 69.

[12] C. Faulmann, S. Dorbes, J. A. Real, L. Valade, J. Low Temp. Phys. 142 (2006) 261.

[13] H. Oshio, K. Kitazaki, J. Mishiro, N. Kato, Y. Maeda, Y. Takashima, J. Chem. Soc. Dalton Trans. (1987) 1341.

[14] S. Hayami, Z.-Z. Gu, H. Yoshiki, A. Fujishima, O. Sato, J. Am. Chem. Soc. 123 (2001) 11644.

[15] S. Hayami, T. Kawahara, G. Juhász, K. Kawamura, K. Uehashi, O. Sato, Y. Maeda, J. Radioanal. Nucl. Chem. 255 (2003) 443.

[16] K. Takahashi, H. Cui, H. Kobayashi, E. Yasuaki, O. Sato, Chem. Lett. 34 (2005) 1240.

[17] K. Takahashi, H.-B. Cui, Y. Okano, H. Kobayashi, Y. Einaga, O. Sato, Inorg. Chem. 45 (2006) 5739.

[18] C. Faulmann, S. Dorbes, S. Lampert, K. Jacob, B. Garreau de Bonneval, G. Molnár, A. Bousseksou, J. A. Real, L. Valade, Inorg. Chim. Acta 360 (2007) 3870.

[19] C. Faulmann, K. Jacob, S. Dorbes, S. Lampert, I. Malfant, M.-L. Doublet, L. Valade, J. A. Real, Inorg. Chem. 46 (2007) 8548.

[20] P. Cassoux, L. Valade, in Inorganic Materials, $2^{\text {nd }}$ ed., d. W. Bruce, D. O’Hare (Eds), (John Wiley \& Sons Ltd.), Chichester, England, 1996.

[21] M. F. Tweedle, L. J. Wilson, J. Am. Chem. Soc. 98 (1974) 4824.

[22] J. Bernstein, Acc. Chem. Res. 28 (1995) 193.

[23] J. Bernstein, J.-O. Henck, Cryst. Eng. 1 (1998) 119.

[24] J. D. Dunitz, J. Bernstein, Acc. Chem. Res. 28 (1995) 193. 
[25] W. C. McCrone, Polymorphism, In Physics and Chemistry of the Organic Solid State Vol. II pp. 726-767; D. Fox, M. M. Labes, A. Weissberger, Eds., Interscience: New York.

[26] H. Spiering, K. Boukheddaden, J. Linares, F. Varret, Phys. Rev. B 70 (2004) 184106-1.

[27] Z. Klencsár, E. Kuzmann, A. Vértes, J. Radioanal. Nucl. Chem. 210 (1996) 105.

[28] CrysAlis CCD and CrysAlis RED, version 1.171.24, Xcalibur CCD system, Oxford Diffraction, 2004.

[29] G. Molnár, T. Guillon, N. Ould Moussa, L. Rechignat, T. Kitazawa, M. Nardone, A. Bousseksou, Chem. Phys. Lett. 423 (2006) 152.

[30] N. N. Greenwood, T. C. Gibb, Mössbauer Spectroscopy, Chapman and Hall, London, 1971.

[31] M.Sorai, S. Seki, J. Phys. Chem. Solids 35 (1974) 555.

[32] M. Sorai, Y. Maeda, H. Oshio, J. Phys. Chem. Solids, 51 (1990) 941.

[33] A. J. Conti, K. Kaji, Y. Nagano, K. M. Sena, Y. Yumoto, R. K. Chadha, A.L. Rheingold, M. Sorai, D.N. Hendrickson Inorg. Chem. 32 (1993) 2681.

[34] E. König, Prog. Inorg. Chem. 35 (1987) 527.

[35] P. Guionneau, M. Marchivie, G. Bravic, J.-F. Létard, D. Chasseau, Top. Curr. Chem. 234 (2004) 97.

[36] A. Bousseksou, J. Nasser, J. Linares, K. Boukheddaden, F. Varret, J. Phys. I 2 (1992) 1381.

[37] A. Galet, A. B. Gaspar, M. C. Muñoz, G. V. Bukin, G. Levchenko, J. A. Real, Adv. Mater. 17 (2005) 2949.

[38] V. Ksenofontov, A. B. Gaspar, P. Gütlich, Top. Curr. Chem. 235 (2004) 23.

[37] J. König, G. Ritter, J. Waigel, H. A. Goodwin, J. Chem. Phys. 1985 (83) 3055.

[38] A. Galet, A. B. Gaspar, G. Agust í, M. C. Muñoz, G. Levchenko, J. A. Real, Eur. J. Inorg. Chem. 2006, 3571.

[39] P. Gütlich, V. Ksenofontov, A. B. Gaspar, Coord. Chem. Rev. 2005 (249) 1811.

[40] A. Galet, A. B. Gaspar, G. Augustí, M. C. Muñoz, J. A. Real, Chem. Phys. Lett. 2007 (434) 68.

[41] E. W. Müller, H. Spiering, P. Gütlich, Chem. Phys. Lett. 1982 (93) 567.

[42] P. Gütlich, A. Hauser, H. Spiering, Angew. Chem. Int. Ed. Engl. 1994 (33) 2024.

[43] J. Jeftić, H. Romstedt, A. Hauser, J. Phys. Chem. Sol. 1996 (57) 1743.

[44] J. Jeftić, R. Hinek, S. C. Capelli, A. Hauser, Inorg. Chem. 1997 (36) 3080.

[45] G. Molnár, T. Kitazawa, L. Dubrovinsky, J. J. McGarvey, A. Bousseksou, J. Phys. Cond. Mat. 2004 (16) S1129.

[46] V. Ksenofontov, H. Spiering, A. Schreiner, G. Levchenko, H. A. Goodwin, P. Gütlich, J. Phys. Chem. Sol. 1999 (60) 393. 